\title{
Water Potential Management and Arrangement of River Estuary Area for the Mitigation of the Climate Change in Bali
}

\author{
I Gusti Agung Putu Eryani", I Wayan Runa", Made Widya Jayantari* \\ \# Civil Engineering, Warmadewa University, Denpasar, 80239, Indonesia \\ E-mail: eryaniagung@gmail.com \\ * Institut Teknologi Sepuluh Nopember Surabaya, Surabaya, 60111, Indonesia \\ E-mail: widyajayantari13@gmail.com
}

\begin{abstract}
The impact of climate change in the form of rising temperatures, rising water levels, water pollution and extreme climate events are vulnerable to the potential of water resources in various sectors of life. The aim of this research is to build a method for managing water potential in river estuaries and arrangement the river estuary area for mitigation of the effects of climate change on water resources in the estuary area, especially in Bali. The method of this research is qualitative research on phenomenology that is happening. Data is collected in the form of primary data and secondary data. Primary data consists of environmental conditions in river estuaries related to climate change that occur, while secondary data in the form of water potential, water quality and land changes are obtained from various related instances. The results of the research found that watersheds on Bali Island are potential watersheds that can be used as raw water sources for both clean water and irrigation water. However, changes in land functions and climate change can cause some negative impacts on the potential and environmental conditions of estuary water resources such as floods, droughts, landslides, pollution of water by pollutants and sedimentation. Mitigation actions that must be taken to reduce the risk for the condition of water resources in river estuaries in Bali due to climate change are managing water potential by managing water systems, conducting water-saving campaigns, integrated management of water availability and needs, environment-based management, strengthening institutions in management of water resources, and the need to regulate cropping patterns right in the river estuary. While in terms of arrangement river estuary area there are several mitigation actions that can be carried out such as the construction of dikes around the estuary area, the construction of reservoirs, the construction of monitoring posts for river estuary conditions and the preservation of deforested areas around river estuary.
\end{abstract}

Keywords — water potential; arrangement; River Estuary; mitigation; climate change.

\section{INTRODUCTION}

Changes in land use and climate change can lead to changes in the condition of water resources, both in terms of quality and quantity. The use of water resources for various purposes on the one hand continues to increase from year to year as a result of population growth and development of activities. On the other hand, the availability of increasingly limited water resources even tends to be increasingly scarce, mainly due to the deterioration of environmental quality and decreasing quality due to pollution [1].

Based on the results of the World Water Forum II in The Hague in the Netherlands, in March 2000 many countries are predicted to experience a water crisis in 2025 , one of them is Indonesia [2]. This is directly related to global issues that have recently become increasingly the world community is talking about climate change and global warming.
Climate change can also cause adverse impacts on the condition of existing water resources. Climate change results in direct hazards in the form of changes in rainfall, where the rainy season lasts shorter with increased intensity and a longer dry season which can cause dad impact of drought, besides the impacts of climate change are rising temperatures, rising water levels, water pollution and extreme climate.

Indonesia as an archipelago consisting of large islands and small islands is very vulnerable to climate change. One of the islands in Indonesia that is vulnerable to climate change is the island of Bali. This is certainly very influential on water resources in Bali. One of them is the river estuary in Bali island which is used as one of the water sources. River estuary is the downstream part of the river that is related to the sea and is still affected by tides. The river estuary area can provide benefits for social and economic interests, indicated by the potential of water both in quantity 
and quality of water, the ability to channel water, the height of rainfall, and related to agricultural needs, clean water, and waste water management.

As a result of climate change, there will be an increase in sea water and increased rainfall intensity which will have a dangerous impact on the river estuary area such as floods that can damage the land around the river estuary such as rice fields, fish ponds, mangroves and so on. In addition, floods can also cause water pollution due to garbage and sedimentation carried by the flow of rainwater through the river. On the other hand, during the dry season due to climate change there will be drought around the river estuary.

Because of the importance of water in various sectors of life and the phenomena due to climate change, it is necessary to have a method of managing the potential of water in the estuary and arrangement the river estuary area to mitigate the effects of climate change in the river estuary in Bali. With the management of water potential and arrangement of the estuary area, it is hoped that it can maintain the availability of water and reduce the impacts of damage to the estuary due to global climate change.

The purpose of this study was to determine the impact of climate change on river estuary areas in Bali Island, mitigation methods for managing water potential in an integrated system at the river estuary and to determine the arrangement of river estuaries are to mitigate the effects of climate change on river estuary.

\section{MATERIAL AND METHODS}

\section{A. Research Materiasl and Methods}

This research uses a qualitative method of phenomenology that is happening. Data collected in the form of primary data and secondary data. Primary data consists of environmental conditions in the estuary related to climate change that occurs, while secondary data in the form of water potential, water quality and land changes are obtained from various related institutions such as the Ministry of Public Works, Bali-Penida River Region Hall, and Bali Provincial Environment Agency and related previous researches.

\section{B. Research Locations}

This research took samples in several river estuaries in Bali which have important significance for the surrounding community and have a risk of climate change impacts on the area around the river estuary which includes: Sowan River Estuary in Jembrana Regency which is used as a fairly busy fishing port, Badung river estuary in Denpasar City is used as a reservoir to collect water that is used as a raw water source for the South Kuta area, the Petanu River Estuary in Gianyar which has great potential to be developed as a raw water supplier for the Badung Regency, and the Saba River Estuary in the Regency Buleleng, which is one of the potential watersheds that can be used to meet the needs of raw water, irrigation, and can be used for reservoirs that can produce electricity.

The river estuary area that is used as the location of this research has vulnerability to climate change because of its location in urban areas with an increase in the number of land use changes that might increase the risk of climate change impacts in the region.

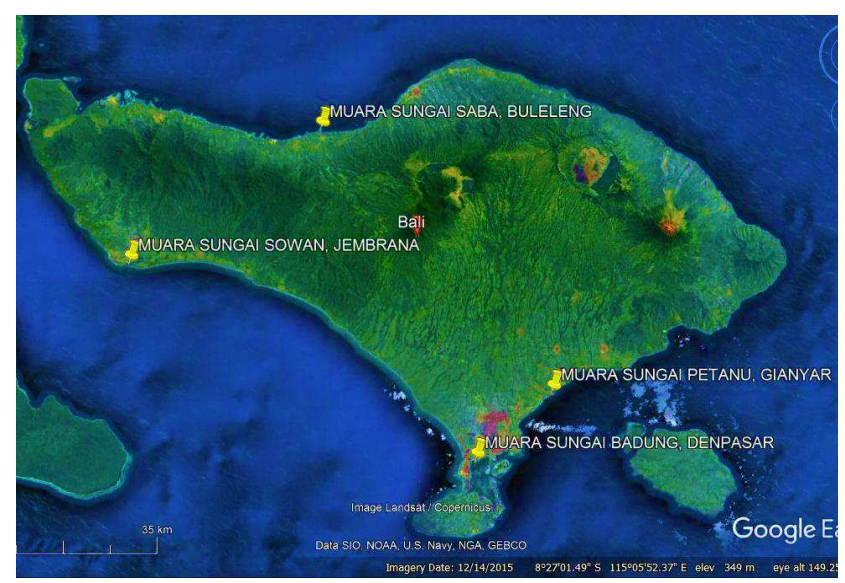

Fig. 1 Research Location

\section{RESULTS AND DISCUSSION}

\section{A. Climate Change in Bali}

The climate of Bali is a tropical sea climate that is influenced by the monsoon which forms two seasons, namely the dry season and the rainy season interspersed with the transition season. Bali Island in general has experienced climate change. The climate type based on SchmidtFerguson changes from relatively wet to somewhat dry. Average monthly air temperature and monthly and annual rainfall have an increasing tendency. Wet months and dry months have experienced shifts and changes in numbers [3].

In 2013 the lowest temperature that occurred in Bali was $20.2^{\circ} \mathrm{C}$ and the highest reached $28.6^{\circ} \mathrm{C}$ with the lowest rainfall of $1936.2 \mathrm{~mm}$ and the highest of $3348.1 \mathrm{~mm}$. Whereas, in 2016 the lowest temperature in Bali Province increased to $26.9^{\circ} \mathrm{C}$ and the highest to $28.4^{\circ} \mathrm{C}$ with the lowest rainfall of $1447 \mathrm{~mm}$ and the highest of $3570 \mathrm{~mm}$. This shows that in 2016 the lowest rainfall decreases, this could indicate that in 2016 it is drier than in 2013, while the highest rainfall increases from 2013 to 2016 this indicates that climate change is actually causing increased rainfall intensity in the rainy season and in the dry season drought will occur [4].

Bali Island is one of the island in Indonesia which is estimated to have a high risk of climate change impacts. The increase in population, reduced forest area, inadequate flood control channels and waste management as well as regional spatial planning that does not pay attention to climate risk will cause the level of vulnerability of Bali Island to be higher. This also affects the existence of water resources in the Province of Bali. One of them affects the river estuary in Bali. River estuary is used as a source of raw water and irrigation water in Bali. Climate change will affect the potential of water in the estuary and the impact of damage to the river estuary can also occur due to climate change that occurs.

\section{B. Water Resources Condition in Bali River Estuary}

\section{B.1 Sowan River Estuary}

\section{1) Water Potential}


Sowan River Estuary is one of the river estuaries in Bali located in Jembrana Regency. This river estuary is used as a fishing port that is quite crowded. The water potential in the Sowan Perancak watershed is $5.59 \mathrm{~m}^{3} / \mathrm{sec}$. Consisting of ground water $0.26 \mathrm{~m}^{3} / \mathrm{sec}$, return flow is $0.13 \mathrm{~m}^{3} / \mathrm{sec}$ and water distric is $5.20 \mathrm{~m}^{3} / \mathrm{sec}$. The total availability of utilized for RK is $0.17 \mathrm{~m}^{3} / \mathrm{sec}$, the hospitality industry is 0.0014 $\mathrm{m}^{3} / \mathrm{sec}$ and the wasted amount is $5.42 \mathrm{~m}^{3} / \mathrm{sec}$.

The use of water potential in the Sowan Perancak Watershed has been used for irrigation water needs of 3151 $\mathrm{Ha}$, while for ground water 10,733 liters/second is used for raw water, industrial water tofu and tofu/soybean [5].

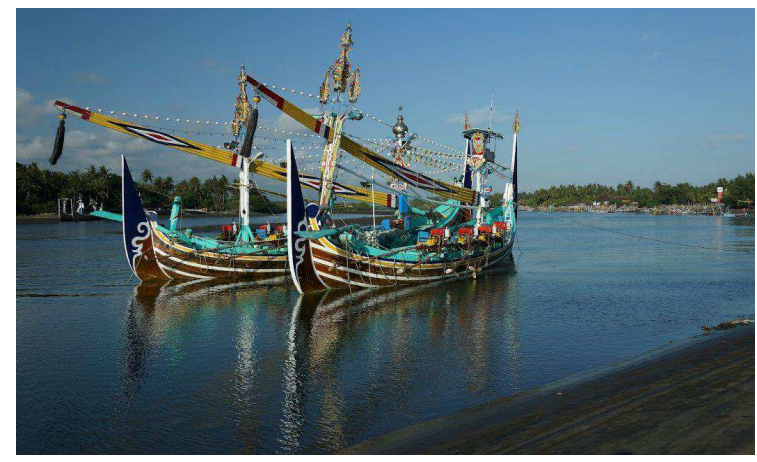

Fig. 2 The Condition of Sowan River Estuary Area

\section{2) Water Quality}

According to the results of measurements of river water quality in the Sowan River Estuary, water quality data obtained from the BOD $10.61 \mathrm{mg} / \mathrm{l}$ and COD levels were $16.47 \mathrm{mg} / \mathrm{l}[6]$.

\section{3) Enviromental Condition}

The downstream area of the Sowan Perancak watershed passes through the capital city of the Jembrana regency. The city area is a densely populated area so that many settlements are found on the banks of the river.

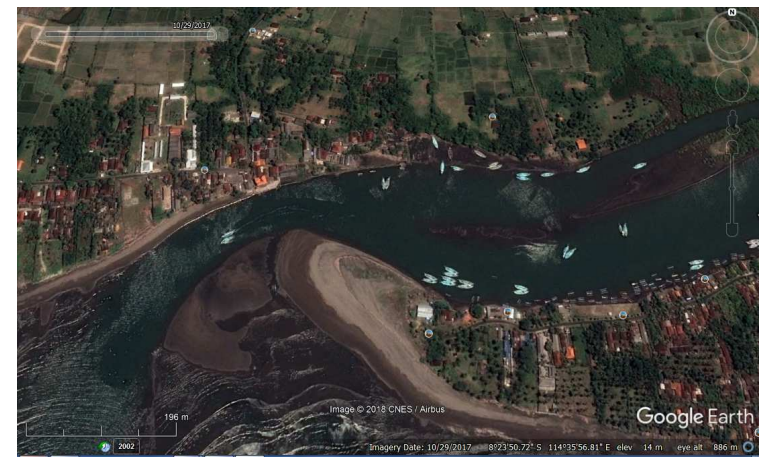

Fig. 3. The Environmental Condition around the Sowan River Estuary Area

\section{B.2 Badung River Estuary}

\section{1) Water Potential}

Badung River Estuary located in Denpasar City. Its strategic position, which is through Denpasar City, makes Badung River an important role. In Badung River several supporting facilities/infrastructures have been built, especially in the field of water resources such as dams used to support the fulfilment of irrigation water and so forth. The potential in the Badung watershed is $6.27 \mathrm{~m}^{3} / \mathrm{sec}$. Consisting of ground water $0.34 \mathrm{~m}^{3} / \mathrm{sec}$, return flow is 1.78 $\mathrm{m}^{3} / \mathrm{sec}$ and water distric is $4.15 \mathrm{~m}^{3} / \mathrm{sec}$. The total availability of used for irrigation is $1.71 \mathrm{~m}^{3} / \mathrm{sec}$, RK is $0.92 \mathrm{~m}^{3} / \mathrm{sec}$, the hotel industry is $0.01 \mathrm{~m}^{3} / \mathrm{sec}$ and the wasted is $4.5 \mathrm{~m}^{3} / \mathrm{sec}$ [5].

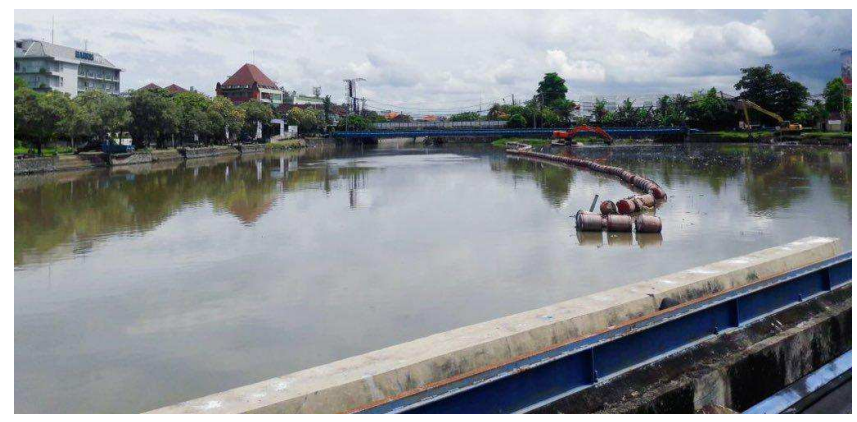

Fig. 4 The Condition of Badung River Estuary Area

\section{2) Water Quality}

According to the results of measurements of river water quality in the Badung River Estuary, water quality data obtained is relatively high in BOD levels ranging from 9.65$10.04 \mathrm{mg} / \mathrm{l}$ and COD levels of 17.12-25.10 mg/l [6].

\section{3) Enviromental Condition}

The downstream of the Badung watershed through the capital city of Bali that is Denpasar. The area of Denpasar city is a densely populated area so that many settlements are found on the banks of the river.

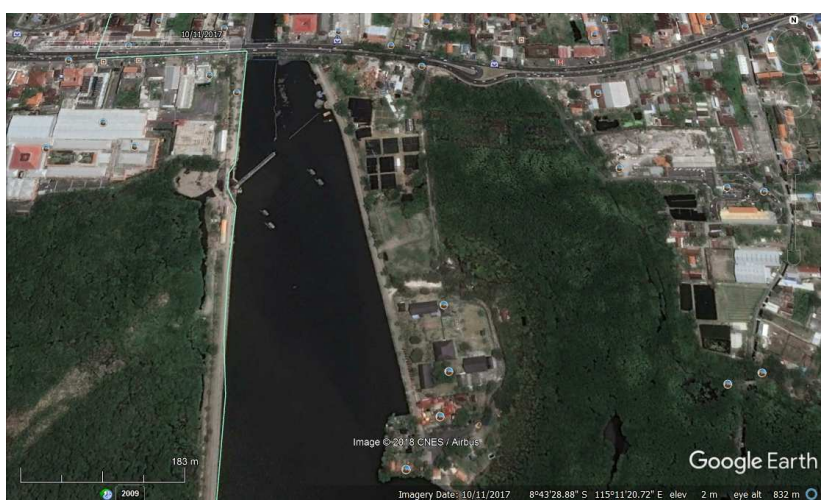

Fig. 5 The Environmental Condition around the Badung River Estuary Area

\section{B.3 Petanu River Estuary}

\section{1) Water Potential}

Petanu River Estuary located in Gianyar Regency. Petanu River is a potential river and crosses 2 Regencies, that is Gianyar and Bangli Regencies. The potential in the Petanu Watershed is $6.86 \mathrm{~m}^{3} / \mathrm{sec}$. Consists of ground water 0.43 $\mathrm{m}^{3} / \mathrm{sec}$, return flow is $3.08 \mathrm{~m}^{3} / \mathrm{sec}$ and water distric is 3.35 $\mathrm{m}^{3} / \mathrm{sec}$. The total availability of utilized for irrigation is 5.25 $\mathrm{m}^{3} / \mathrm{sec}$, RK is $0.13 \mathrm{~m}^{3} / \mathrm{sec}$, the hospitality industry is 0.0022 $\mathrm{m}^{3} / \mathrm{sec}$ and the wasted amount is $5.17 \mathrm{~m}^{3} / \mathrm{sec}$ [5]. 


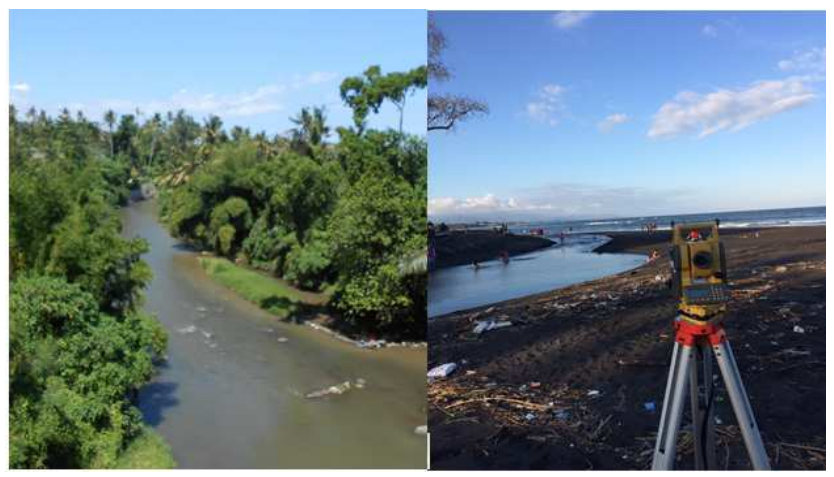

Fig. 6 The Condition of Petanu River Estuary Area

\section{2) Water Quality}

According to the results of measurements of river water quality in the Petanu River Estuary, water quality data obtained from BOD levels ranged from $2.96-3.42 \mathrm{mg} / 1$ and COD levels of 9-12 mg / 1 [7].

\section{3) Enviromental Condition}

The downstream of the Petanu watershed is in the coastal area of Saba. Around the estuary area there are several residential areas, agricultural land and shrines that are used by local people, especially Hindus for religious ceremonies.

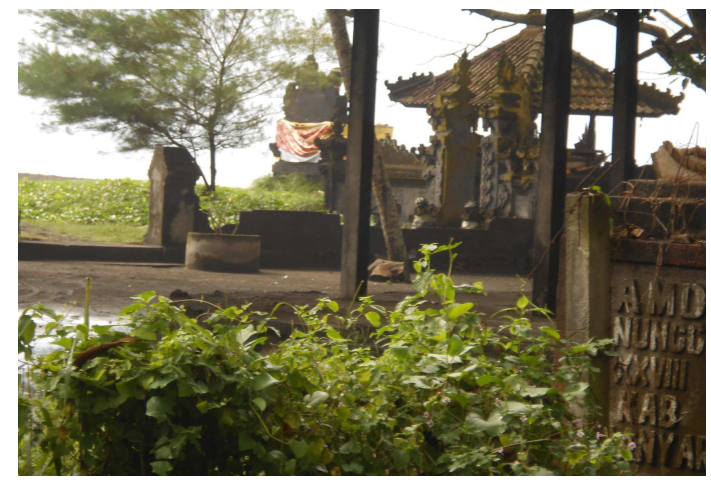

Fig. 7 Holy Region Around the Petanu River Estuary Area

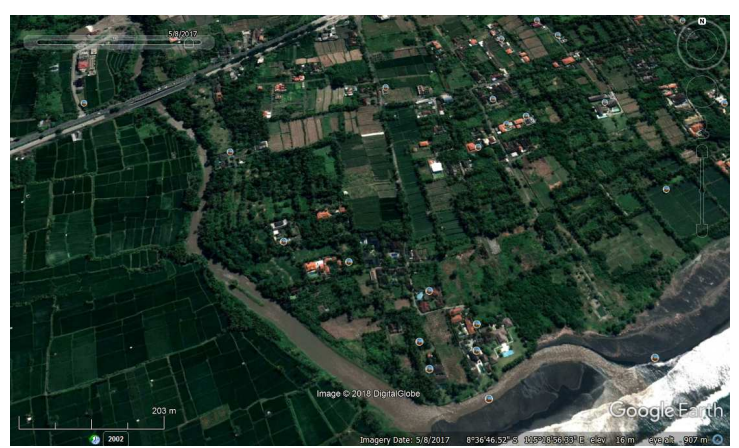

Fig. 8 The Environmental Condition around the Petanu River Estuary Area

\section{B.4 Saba River Estuary}

\section{1) Water Potential}

Saba River Estuary located in Buleleng Regency. Saba River is a potential river and crosses two Regencies that is Buleleng and Tabanan Regencies. The potential in the Saba watershed is $4.29 \mathrm{~m}^{3} / \mathrm{sec}$. Consisting of ground water 0.24 $\mathrm{m}^{3} / \mathrm{sec}$, return flow is $1.76 \mathrm{~m}^{3} / \mathrm{sec}$ and water distric is 2.30 $\mathrm{m}^{3} / \mathrm{sec}$. The total availability of utilized for irrigation is 5.19 $1 / \mathrm{sec} / \mathrm{ha}, \mathrm{RK}$ is $0.09 \mathrm{~m}^{3} / \mathrm{sec}$, the hotel industry is 0.00045 $\mathrm{m}^{3} / \mathrm{sec}$ and the wasted amount is $3.47 \mathrm{~m}^{3} / \mathrm{sec}$ [5].

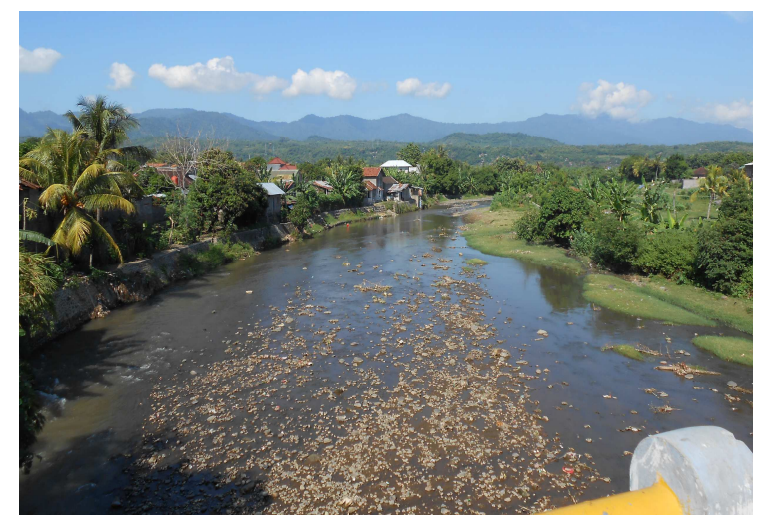

Fig. 9 The Condition of Saba River Estuary Area

\section{2) Water Quality}

According to the results of measurements of river water quality in the Saba River Estuary, water quality data obtained from BOD levels ranged from 4.11-11.36 mg / 1 and COD levels were 17-26 mg / 1 [7].

\section{3) Enviromental Condition}

The downstream of the Saba watershed is a potential river through the two regions of Buleleng and Tabanan regencies. The Saba watershed area is a densely populated area so that many settlements are located on the banks of the river.

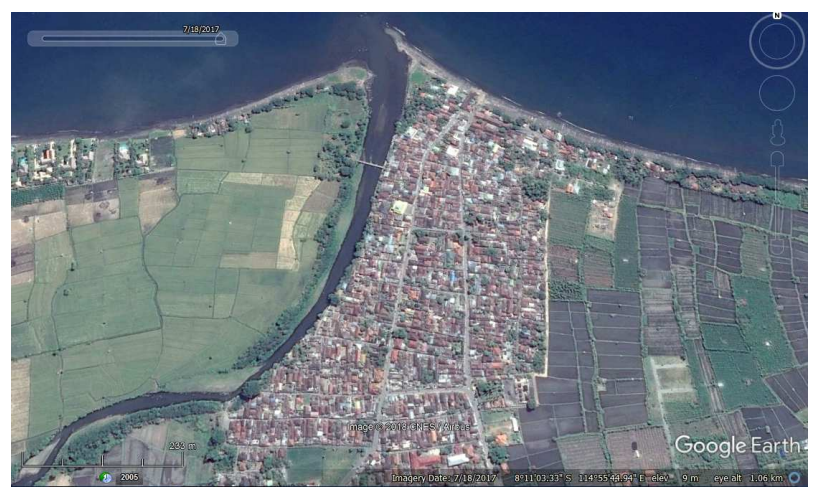

Fig. 10 The Environmental Condition around the Saba River Estuary Area

\section{Impacts that can Occur in The Bali River Estuary Because of Climate Change}

Nowadays, water has become an economic commodity and is expensive because its existence is increasingly scarce, even many are polluted by various wastes from the results of human and household activities, agricultural, livestock, industrial waste and so on. Indicators or signs of contaminated water are changes in water temperature, $\mathrm{pH}$ or hydrogen ion concentration, color, odor and taste of water, the onset of deposits, colloidal dissolved materials, microorganisms and radioactive water.

The area of the city and district is an area that has water resources in the form of potential surface water and 
groundwater. This is evident from several large-sized rivers and springs which are potential sources for the supply of raw water needs for the population. Fluctuations in water discharge that are used to meet irrigation water needs are very diverse and fluctuate over time, the environmental conditions around the river estuary greatly affect this water discharge.

The trend of changing land use from the area rather than being built into a built area and land processing system that is not in accordance with the designation has reached protected areas which should be conserved and climate change can cause problems in the management of water resources.

The general problem in water resources management basically consists of three aspects: too much water, lack of water and water pollution. Increased demand for water has led to excessive exploitation of water resources resulting in a decrease in the environmental carrying capacity of water resources which in turn reduces the ability of water supply.

River estuary is one of the sources of water that can be affected by changes in land function and climate change. Seen in the above explanation about the condition of the environment around the river estuary, where it can be seen that around the banks of the river leading to the estuary looks dense by building residential residents. This can cause several possible impacts of disasters that will occur due to climate change, such as:

\section{1) Flood Disaster}

Flooding is defined as the inundation of a place due to overflowing of water that exceeds the capacity to drain water in an area and causes physical, social and economic losses [8].

Floods that occur in the area around the watershed are generally caused by high rainfall intensity. Climate change will increase the intensity of rain. Besides being able to cause water overflows around the watershed area, with increasing rainfall intensity, the amount of garbage dumped in rivers or garbage carried by rainwater flow and sedimentation carried by rainwater can result in silting of river estuary that can significantly increase the effect to increase frequency flooding due to the capacity of the reservoir which is exceeded by the river discharge.

All regencies/municipalities in Bali have areas that have the potential to flood in terms of aspects of rainfall, slope, river density and land use. Districts/cities in Bali that have relatively large flood-prone areas are Jembrana, Denpasar, Buleleng and Badung Regencies.

\section{2) Drought Disaster}

According to the International Glossary of hydrology, the definition of drought is a state without prolonged rainy or dry period under normal long enough, resulting in seriously disturbed hydrological balance [9]. Climate change can cause an increase in the potential for drought due to climate change causing a shift in the season so that the dry season is much longer than before.

Some regencies in Bali which are potentially droughtprone areas are eastern and western Buleleng Regencies, Klungkung Regencies, especially in the Nusa Penida Region, as well as the southern Badung Regency [10].

\section{3) Landslide Disaster}

Skempton and Hutchinson define landslides or ground movements as movements down the slope by land masses and / or slope-composing rocks due to disturbed soil stability or rock constituent slopes [11].

Climate change can trigger landslides especially in logged-over areas. Nowadays, there has been some change in land use from the area rather than being built into a builtup area that reduces water catchment areas.

Climate change makes rain fall with increasing intensity which causes the soil to become cohesive so that it affects the stability of the soil so that it can cause landslides.

\section{4) Water Pollution}

Climate change that causes changes in temperature and changes in rainfall intensity as well as human activities that live around the watershed will exacerbate the potential for water pollution that occurs in watersheds, especially the estuary. Pollution can be caused by various wastes from the results of human and household activities, agricultural, livestock, industrial waste and so on.

\section{5) Sedimentation in River Estuary}

Sedimentation is defined as transporting, floating (suspension) or settling fragmental material by water [12].

The magnitude of the increased rainfall intensity due to climate change can increase the rate of sedimentation in the river which can cause river estuary closure by sediment. The closure of the river estuary can occur due to the increased rate of sediment from the river and coupled with the rate of sediment from the coast due to the rise in sea level which results in changes in the direction of the current.

\section{Mitigation the impacts of climate change on the management of potential water in river estuarys}

Water is one of the most important needs in human life in various sectors of human life, such as the economic sector, agriculture, domestic, tourism industry and so on. So it needs to be preserved. In dealing with climate change and its impacts, mitigation measures need to be taken in the management of existing water potential.

Mitigation is an attempt to avoid things that cannot be managed. In this case the change effort is carried out on the source of global warming. Mitigation strategies that can be carried out include: Managing water management on downstream rivers in order to reduce the vulnerability of downstream river erosion and flooding due to the impact of greenhouse gas emissions and supporting reforestation activities in critical watersheds and downstream areas and, improving the water-saving campaign. Both strategies above are very important because climate change can also have an impact on the food crisis, global water crisis and energy crisis as a result of extreme climate change conditions.

Integrated water resource management between upstream interests and downstream river interests, integrated management between water quantity and quality, between groundwater and surface water, and between land resources and water resources.

The concept of the spatial planning process at the river estuary based on the carrying capacity of the environment is the way to realize sustainable resource management. 
Forecasts of the amount of supportive capacitycapacity and assimilative allow to identify constraints that must be addressed in spatial planning for equitable socio-economic development by suppressing the negative impacts as small as possible.

Explorative and investigative studies of environmental capacity at river estuarys in the supply of natural resources and the resulting waste capacity make it possible to comprehensively identify the potential of available water resources. Thus, the SDA can be allocated (through arrangement the river estuary and beach) to obtain optimal benefits with minimal negative impacts.

Improving integrated water resource management by strengthening institutional users and supervision of water resources utilization, empowering communities to use water resources efficiently and managing water resources in a sustainable and balanced manner.

Arrange the pattern of crop rotation in the area of the river estuary so that at the time of the drought plant crops that do not need much water, while during the rainy season can plant crops that need enough water.

\section{E. Arrangement River Estuary Area for Mitigation of Global Climate Change Impacts}

In addition to mitigation in the management of water potential, the arrangement of river estuary areas is also an important thing that must be done to reduce the risk of damage to the area due to the impacts of climate change.

The river estuary arrangement that can be done to mitigate climate change is the following steps: (a). Construction of safety dikes and arrangement of river banks in the downstream areas of the river and buildings at the jetty river estuary; (b). The reservoir is made as a water storage device and also as a flood control building and door water level controller in the downstream of the river; (c). Built post/monitoring tower on the beachside to monitor environmental conditions and water discharge in the downstream area of the river; (d). Environmental preservation in the area of the estuary and the beach by replanting deforested lands.

\section{CONCLUSIONS}

Bali is one of the provinces in Indonesia is vulnerable to climate change. The watershed area on Bali island is a potential watershed that can be used as a source of raw water for both clean water and irrigation water. However, changes in land function and climate change can cause some negative impacts on the potential and environmental conditions of estuary water resources such as floods, droughts, landslides, water pollution by pollutants and sedimentation. Therefore there is a need for mitigation measures to reduce the risk caused by climate change on water resources in the River Estuary in Bali. There are several things that can be done as mitigation measures in managing the potential of water in river estuaries on Bali island including water management, conducting water-saving campaigns, integrated management between water availability and needs, environment-based management, strengthening institutions in managing resources water, and there is a need to adjust the cropping pattern right in the river estuary. In terms of arrangement the river estuary there are a number of mitigation actions that can be carried out including construction of dikes around the river estuary area that are considered to have vulnerability to landslides, the construction of reservoirs as water reservoirs when excessive rainfall and can be used during droughts, construction of estuary condition monitoring posts rivers and preservation of barren areas around river estuarys.

\section{REFERENCES}

[1] Sundra, I Ketut. Condition and the Level of Water Pollution in Bali. Biology Department of Science and Mathematic Faculty on Udayana University. 2017.

[2] Subagyono K and ES. Management of Climate and Water Resources to Anticipate Climate Change. Meteorology and Geophysics Journal. 2007; 8 (1): 27-41.

[3] Setiawan O. Analysis of Variability in Rainfall and Temperature in Bali. Journal of Forestry Policy Analysis. 2012; 9 (1): 66-79.

[4] Central Bureau of Statistics. Bali in Numbers 2017.

[5] PT. Indra Karya Konsultan. Final Report on the Preparation of the Bali-Penida River Water Resources Management Plan (Phase I). General of Water Resources, Bali-Penida River Region Hall 2017.

[6] Eryani, I Gusti Agung Putu, I Nengah Sinarta and INS. Changes in the function of land in the river estuary against the preservation of water resources. Jurnal Bumi Lestari. 2014; 14 (1): 85-90.

[7] Eryani IGAP. Water Potential of Petanu and Saba River Estuary as Water Resources Management Models in Bali Province. Dissertation, Udayana University; 2015.

[8] Rahayu, Harkunti P. 2009. Floods and countermeasures. Bandung: Promise Indonesia.

[9] [WMO]. World Meteorological Organization. 1974. International Glossary of Hydrology. Geneva (CH). WMO-No.385.

[10] Bali Provincial Government. Report of the Bali Provincial Environmental Status in 2010

[11] Skempton, A.W., and Hutchinson. 1969. Stability of Natural Slope and Embankment Foundations. In Slope Stability and Stabilization Methods, 1996, Abramson, L.W., Lee, T.S., Sharma, S., and Boyce, G.M., John Wiley and Sons, Inc, New York.

[12] Gemilang, W. A., Wisha, U. J., Kusumah, G. 2017. Distribution of basic sediments as identification of coastal erosion in Brebes District using granulometric analysis. J. Marine 10 (1): 54-66. 